
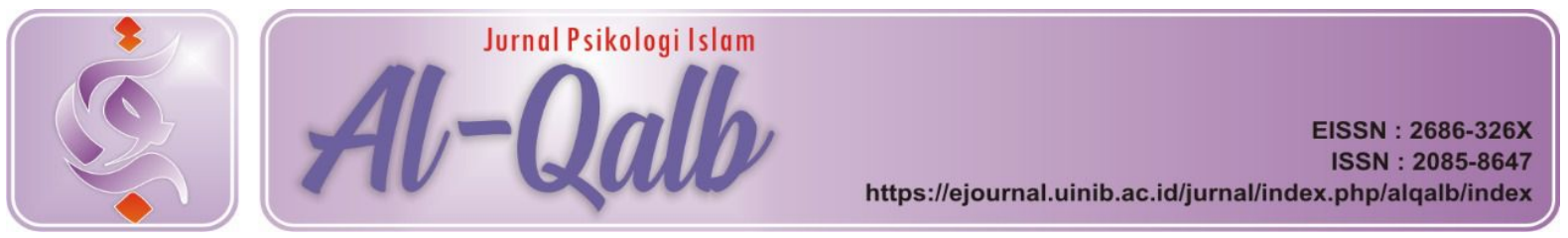

\title{
ANALISIS KEPUASAN KERJA DAN KUALITAS PELAYANAN
}

Received: $21^{\text {th }}$ June 2015; Revised: $24^{\text {th }}$ July 2015; Accepted: $25^{\text {th }}$ August 2015

\section{Liesma Maywarni Siregar}

Universitas Muhammadiyah Sumatera Barat

Email: liesmamsiregar@gmail.com

\begin{abstract}
Abstrak: Kepuasan kerja sebagai hasil keseluruhan dari derajat rasa suka atau tidak sukanya karyawan terhadap berbagai aspek dari pekerjaannya. Ada dua faktor yang mempengaruhi kepuasan kerja karakteristik individu dan karakteristik pekerjaan. Kepuasan kerja dapat menghasilkan dampak positif maupun negatif. Efek dari kepuasan kerja mempengaruhi kualitas pelayanan karyawan terhadap pelanggan. Dengan demikian kepuasan kerja mempunyai hubungan sebab akibat dengan kualitas pelayanan.
\end{abstract}

Kata kunci: Kepuasan Kerja, Kualitas Pelayanan

Kepuasan dalam bekerja merupakan harapan setiap orang yang bekerja. Pada dasarnya kepuasan kerja merupakan hal yang bersifat individual karena setiap individu akan memiliki tingkat kepuasan yang berbeda-beda sesuai dengan nilai-nilai yang berlaku dalam diri setiap individu. Semakin banyak aspek dalam pekerjaan yang sesuai dengan keinginan individu, maka semakin tinggi tingkat kepuasan yang dirasakan.

Terdapat beberapa pengertian kepuasan kerja, di antaranya Howell dan Robert (1986) memandang kepuasan kerja sebagai hasil keseluruhan dari derajat rasa suka atau tidak sukanya karyawan terhadap berbagai aspek dari pekerjaannya. Kemudian (Riggio, 2009) kepuasan kerja merupakan perasaan dan sikap seseorang tentang pekerjaan seseorang atas semua aspek pekerjaan tertentu, baik dan buruk atau positif dan negatif. Sedangkan kepuasan kerja menurut (Robbins dan Judge, 2001) adalah merupakan sebagai suatu perasaan positif tentang pekerjaan seseorang yang merupakan hasil dari sebuah evaluasi karakteristiknya.

Definisi lainnya dikemukakan oleh Spector (dalam Yuwono, 2005) yaitu kepuasan kerja dianggap sebagai perasaan umum tentang pekerjaan atau juga sebagai hubungan konstelasi dari sikap tentang berbagai aspek (facet) pekerjaan. Perasaan tersebut berkisar antara kesukaan atau kepuasan terhadap pekerjaannya ataupun ketidaksukaan atau ketidakpuasan terhadap pekerjaannya.

Menurut Spector (2012) job satisfaction is an attitudinal variable that reflects how people feel about their jobs overall, as well as various aspects of the job. In simple terms, job satisfaction is the extent to which people like their jobs and jobs satisfaction is extent to which they dislike them. Kepuasan kerja merupakan variabel sikap yang merefleksikan bagaimana perasaan individu mengenai pekerjaannya secara keseluruhan aspek yang ada didalamnya, dengan kata lain kepuasan kerja memiliki nilai sejauh mana individu suka (kepuasan) dengan 
pekerjaannya dan sejauh mana individu tidak suka (ketidakpuasan) terhadap pekerjaannya. Teori kepuasan kerja dari Spector juga menyebutkan bahwa kepuasan kerja sebagai variabel sikap yang merefleksikan perasaan evaluatif tentang pekerjaan melaluai sembilan aspek (facet) dari pekerjaan.

Aspek-aspek kepuasan kerja tersebut antara lain: upah (jumlahnya dan rasa keadilannya), promosi (peluang dan rasa keadilan untuk mendapatkan promosi), supervisi (keadilan dan kompetensi penugasan managerial oleh penyelia), benefits (tunjangan luar gaji termasuk asuransi, liburan dan bentuk fasilitas lain), contigent reward (rasa hormat, diakui, diberikan apresiasi), operating procedures (kondisi peru-sahaan, termasuk peraturan serta prosedurnya), coworkers ( rekan kerja yang menyenangkan dan kompeten), nature of work (tugas itu sendiri dapat dinikmati atau tidak), dan communication (berbagi informasi di dalam organisasi baik verbal atau tulisan) (Yuwono, 2005).

\section{Aspek Kepuasan Kerja}

Spector tahun 1997 (dalam Yuwono, 2005) menyebutkan bahwa terdapat sembilan aspek yang mempengaruhi kepuasan kerja yaitu:

1. Kepusan kerja terhadap gaji yang diterima dan kesempatan mem-peroleh kenaikan gaji.

2. Kepuasan kerja terhadap kesempatan promosi untuk kenaikan jabatan.

3. Kepuasan kerja terhadap atasan.

4. Kepuasan kerja terhadap tunjangantunjangan diluar gaji (benefits).

5. Kepuasan kerja terhadap reward yang diterima saat karyawan menunjukan performa yang baik atau prestasi dalam pekerjaan, tidak selalu berupa uang (contingent rewards).

6. Kepuasaan kerja terhadap kondisi perusahaan, termasuk mengenai peraturan serta prosedurnya.
7. Kepuasan kerja terhadap rekan, termasuk interaksi dan kerjasama dengan sesama rekan kerja.

8. Kepuasaan kerja terhadap tipe pekerjaan yang harus dikerjakan.

9. Kepuasan kerja terhadap komu-nikasi di dalam organisasi, ter-masuk komunikasi yang terjadi dengan sesama teman kerja, baik atasan maupun bawahan.

\section{Faktor-faktor yang Mempenga-ruhi Kepuasan Kerja}

Banyak faktor-faktor yang menentukan kepuasan kerja, faktor-faktor tersebut dapat dibagi menjadi dua bagian yaitu karakteristik individu dan karakteristik peker-jaaan.

Beberapa aspek yang termasuk dalam karakteristik individu adalah perbedaan individu, usia, pendidikan dan kecerdasan, jenis kelamin, dan jabatan.

a. Perbedaan individu

Pada umumnya, hasil-hasil penelitian tentang kepuasan kerja berkaitan dengan perbedaan individu yang mengarah pada diri sendiri, pekerjaan, dan perusahaan tempat bekerja. Selanjutnya, Bidwell (1955) menunjukkan bahwa kepuasan kerja berhubungan dengan harapan peran yang ingin dicapai oleh sebagian karyawan (dalam Wijono, 2010).

Atas dasar itu dapat disimpulkan bahwa perbedaan individu dan situasi yang berbeda dapat menghasilkan kepuasan kerja yang berbeda juga. Setiap perbedaan individu mempunyai tahap kepuasan kerja menurut tingkat yang ditetapkan oleh individu sendiri. Hal ini menyebabkan ada perbedaan tingkat kepuasan bagi setiap perbedaan individu.

\section{b. Pendidikan dan kecerdasan}

Hubungan antara pendidikan dan kecerdasan dengan kepuasan kerja tidak begitu jelas. Ash (1954) menemukan bahwa ada hubungan signifikan di antara kecerdasan dan kepuasan kerja. Sementara itu, Suehr (1962) melaporkan bahwa ada hubungan yang negatif dan signifikan 
antara kecerdasan (intelligence) dan pendidikan moral (dalam Wijono, 2010).

Sementara itu, Vollmer dan Kinney (1955) menemukan bahwa ada hubungan negatif antar-pendidikan dan kepuasan kerja. Demikian juga Sinha dan Sarma (1962) melaporkan bahwa tidak ada hubungan yang signifikan antara pendidikan dan kepuasan kerja (dalam Wijono, 2010).

Jadi, dapat dikatakan bahwa kedua faktor tersebut dapat memberi pengaruh terhadap kepuasan kerja, walaupun demikian ada penelitian yang menunjukkan tidak ada hubungan antara pendidikan, kecerdasan, dan kepuasan kerja.

\section{c. Jenis kelamin}

Hulin dan Smith (1964) menemukan bahwa faktor demografi jenis kelamin tidak mempengaruhi tinggi atau rendahnya kepuasan, tetapi faktor-faktor lain yang ada hubungannya dengan jenis kelamin, seperti gaji, jabatan, dan peluang kenaikan tingkat. Hasil penelitian Zaleznik, Christensen, dan Roethlisberger (1958) menemukan bahwa perempuan lebih puas dibandingkan dengan laki-laki. Mereka juga menunjukkan bahwa perempuan berada pada tahap sosial yang sama dan mendapat gaji yang sama dengan laki-laki (dalam Wijono, 2010).

\section{d. Jabatan}

Jabatan merupakan salah satu faktor yang dapat mempengaruhi kepuasan kerja. Jabatan yang ada, dapat diklasifikasikan ke dalam beberapa cara seperti keterampilan dan keahlian, jangka waktu latihan, jumlah tanggung jawab sosial, ataupun sikap kerja dapat mempengaruhi kepuasan kerja individu.

Gurin, Veroff, dan Feld (1960) menemukan bahwa individu yang mempunyai jabatan yang tinggi memperoleh kepuasan kerja yang lebih tinggi karena egonya terpuaskan dibandingkan dengan individu yang memegang jabatan yang lebih rendah (dalam Wijono, 2010).

Sedangkan faktor-faktor berdasarkan karakteristik pekerjaan ditinjau dari ciriciri intrinsik dari pekerjaan, gaji dan penyeliaan. Menurut Locke, ciri-ciri intrinsik dari pekerjaan yang menentukan kepuasan kerja ialah keragaman, kesulitan, jumlah pekerjaan, tanggung jawab, otonomi, kendali terhadap metoda kerja, kemajemukan, dan kreativitas (Munandar, 2011).

Sedangkan dari faktor sistem penggajian, menurut penelitian dari Theriault kepuasan kerja merupakan fungsi dari jumlah absolut dari gaji yang diterima, derajat sejauh mana gaji memenuhi harapan-harapan tenaga kerja, dan bagaimana gaji diberikan (Munandar, 2011). Jadi yang menjadi penting adalah sejauh mana gaji yang diterima dirasakan adil. Jika gaji dipersepsikan sebagai adil didasarkan tuntutan-tuntutan pekerjaan, tingkat keterampian individu, dan standar gaji yang berlaku untuk kelompok pekerjaan tertentu, maka akan ada kepuasan kerja.

Dilihat dari sisi penyeliaan atau hubungan atasan dan bawahan peran kepemimpinan, hasil penelitian menunjukkan bahwa hanya ada satu ciri kepemimpinan yang secara konsisten berkaitan dengan kepuasan kerja, yaitu penenggang rasa (consideration) (Munandar, 2011).

Selain itu, kondisi kerja yang tidak mengenakkan (uncomfortable) akan menimbulkan keengganan untuk bekerja. Kondisi kerja yang memperhatikan prinsip-prinsip ergonomi, sehingga dalam kondisi kerja seperti itu kebutuhan fisik dipenuhi dan dapat memuaskan tenaga kerja (Munandar, 2011).

\section{Dampak Kepuasan Kerja}

Kepuasan kerja bisa menghasilkan dampak positif maupun negatif. Terdapat beberapa dampak besar dari kepuasan kerja, yaitu employee withdrawal (termasuk 
tingkat kehadiran dan tingkat keryawan keluar dari perusahaan), peforma karyawan (termasuk produktivitas dan perilaku Organizational Citizenship Behavior (OCB)), serta pada kesehatan fisik dan kesejahteraan psikologis karyawan.

1. Penarikan diri karyawan (employee
withdrawal)

a. Tingkat kehadiran (absen)

Spector (2012) mengemukakan

kebijakan dahulu menunjukkan bahwa ketidakhadiran kerja merupakan dampak dari ketidakpuasan karyawan terhadap pekerjaannya. Orang-orang yang tidak menyukai pekerjaan mereka lebih cenderung untuk menghindari pekerjaan daripada orang yang menyukai pekerjaan mereka. Beberapa meta analisis menunjukkan bahwa hubungan antara kepuasan kerja dan ketidakhadiran tidak konsisten dan biasanya cukup kecil.

b. Tingkat karyawan keluar dari perusahaan (turnover)

Menurut Spector (2012) dampak dari kepuasan kerja pada akhirnya yaitu berhenti bekerja. Banyak penelitian menunjukan bahwa yang tidak puas atas pekerjaannya lebih mungkin berhenti dari pekerjaannya dibandingan karyawan yang puas dengan pekerjaannya. Korelasi antara kepuasan kerja dan berhenti bekerja telah ditafsirkan sebagai dampak kepuasan terhadap perilaku. Kebanyakan penelitian tentang berhenti bekerja menilai kepuasan kerja dalam sampel karyawan pada satu kesempatan dan kemudian menunggu beberapa periode bulan atau tahun untuk melihat karyawan yang berhenti. Prediksi dari penelitian ini menyimpulkan bahwa ada kemungkinan ketidakpuasan adalah sebuah faktor yang mengarah pada karyawan untuk berhenti dari pekerjaan mereka.
2. Performa karyawan

a. Produktivitas

Terdapat pandangan bahwa kepuasan kerja mungkin merupakan akibat, dan bukan merupakan sebab dari produktivitas. Lawler dan Porter mengharapkan produk-tivitas yang tinggi menyebabkan peningkatan dari kepuasan kerja hanya jika tenaga kerja mempersepsikan bahwa ganjaran intrinsik (misalnya rasa telah mencapai sesuatu) dan ganjaran ekstrinsik (misalnya gaji) yang diterima kedua-duanya adil, wajar, dan diasosiasikan dengan unjuk kerja yang unggul.

b. Perilaku Organizational Citizenship Behavior (OCB)

Spector menyatakan bahwa Organizational Citizenship Behavior (OCB) adalah perilaku karyawan yang diarahkan untuk membantu rekan kerja atau organisasi tanpa harus memper-timbangkan apa yang akan diperoleh dari rekan kerja atau organisasi nantinya (dalam Yuwono, 2005).

3. Kesehatan fisik karyawan Menurut Spector ketidakpuasan kerja mungin merupakan faktor penting dalam kesehatan karyawan dan kesejahteraan. Penelitian menunjukkan bahwa adanya korelasi antar kepuasan kerja dan berbagai masalah kesehatan. Sebagai contoh, penelitian Bowling \& Hammond (2008) karyawan yang tidak puas atas pekerjaannya dilaporakan disebabkan oleh gejala-gejala psikologis, seperti masalah tidur dan masalah pada perut, daripada rekanrekan mereka yang puas. Ketidakpuasan juga berhubungan dengan emosi negatif di tempat kerja, seperti kecemasan dan depresi. Emosi negatif ini dapat dianggap 
sebagai indikator kesehatan psikologis atau kesejahteraan di tempat kerja. Bukti sehubungan dengan kepuasan kerja untuk masalah kesehatan yang lebih serius, seperti penyakit jantung, telah menyebabkan sulit untuk menghasilkan sebuah peker-jaan.

\section{Kualitas Pelayanan}

Banyak defenisi kualitas pelayanan yang dikemukakan oleh para ahli. Antara lain menurut Goetsch \& Davis (1994) (dalam Tjiptono, 2011) mendefenisikan kualitas sebagai kondisi dinamis yang berhubungan dengan produk, jasa, sumber daya manusia, proses, dan lingkungan yang memenuhi atau melebihi harapan. Menurut Kotler (dalam Tjiptono, 2011) mendefenisikan jasa sebagai setiap tindakan atau perbuatan yang dapat ditawarkan oleh suatu pihak ke pihak lain yang pada dasarnya bersifat intangible (tidak berwujud fisik) dan tidak menghasilkan kepemilikan sesuatu.

Sedangkan menurut Lewis \& Booms (1983) (dalam Tjiptono, 2011) merupakan pakar yang pertama kali mendefenisikan kualitas jasa sebagai ukuran seberapa besar tingkat layanan yang diberikan mampu sesuai dengan ekspektasi pelanggan. Berdasarkan defenisi ini, kualitas jasa diwujudkan melalui pemenuhan kebutuhan dan keinginan pelanggan serta ketepatan penyampaiannya untuk mengimbangi harapan pelanggan.

Defenisi lainnya menurut

Parasuraman, Zeithaml, dan Berry (1990) service quality as perceived by customers, can be defined as the extent of discrepancy between customers' expectation or desires and their perceptions. Kualitas pelayanan seperti yang dirasakan oleh pelanggan, dapat didefinisikan sebagai sejauh mana perbedaan antara harapan pelanggan atau keinginan dan persepsi mereka.

\section{Dimensi Kualitas Pelayanan}

Melalui serangkaian penelitian terhadap berbagai macam industri jasa, Zeithaml, dan Berry (dalam Tjiptono, 2011) mengidentifikasikan sepuluh dimensi pokok kualitas jasa yaitu:

1. Reliabilitas, meliputi dua aspek utama, yaitu konsistensi kinerja (performance) dan sifat dapat dipercaya (dependability). Hal ini berarti perusahaan mampu menyampaikan jasanya secara benar sejak awal (right the first time), memenuhi janjinya secara akurat dan andal (misalnya, menyampaikan jasa sesuai dengan jadwal yang telah disepakati), menyimpan data (record) secara tepat, dan mengirimkan tagihan yang akurat.

2. Responsivitas atau daya tanggap, yaitu kesediaan dan kesiapan para karyawan untuk membantu para pelanggan dan menyampaikan jasa secara cepat. Beberapa contoh diantaranya: ketepatan waktu layanan, pengiriman slip transaksi secepatnya, kecepatan menghubungi kembali pelanggan, dan penyampaian layanan secara cepat.

3. Kompetensi, yaitu penguasaan keterampilan dan pengetahuan yang dibutuhkan agar dapat menyampaikan jasa sesuai dengan kebutuhan pelanggan. Termasuk di dalamnya adalah pengetahuan dan keterampilan karyawan kontak, pengetahuan dan keterampilan personil dukungan operasional, dan kapabilitas riset organisasi.

4. Akses, meliputi kemudahan untuk dihubungi atau ditemui (approachability) dan kemudahan kontak. Hal ini berarti lokasi fasilitas jasa mudah dijangkau, waktu mengantri atau menunggu tidak terlalu lama, saluran komunikasi perusahaan mudah dihubungi, dan operasi nyaman.

5. Kesopanan (Courtesy), meliputi sikap santun, respek, atensi, dan 
94 Jurnal Al-Qalb, Jilid 7, Nomor 2, September 2015, hlm. 89-99

keramahan para karyawan kontak (seperti resepsionis, operator telepon, bell person, teller bank, dan lainlain).

6. Komunikasi, artinya menyam-paikan informasi kepada para pelanggan dalam bahasa yang mudah mereka pahami, serta selalu mendengarkan saran dan keluhan pelanggan. Termasuk di dalamnya adalah penjelasan mengenai jasa atau layanan yang ditawarkan, biaya jasa, trade-off antara jasa dan biaya, serta proses penanganan masalah potensial yang mungkin timbul.

7. Kredibilitas, yaitu sifat jujur dan dapat dipercaya. Kredi-bilitas mencakup nama perusahaan, reputasi perusa-haan, karakter pribadi karyawan, dan interaksi dengan pelanggan (hard selling versus soft selling approach).

8. Keamanan (Security), yaitu bebas dari bahaya, risiko atau keraguraguan. Termasuk di dalamnya adalah keamanan secara fisik (physical safety), keamanan financial (financial security), privasi, dan kerahasiaan (confidentiality).

9. Kemampuan memahami pelanggan, yaitu berupaya memahami pelanggan dan kebutuhan spesifik mereka, memberikan perhatian individual, dan mengenal pelanggan reguler.

10. Bukti fisik (Tangibles), meliputi penampilan fasilitas fisik, peralatan personil, dan bahan-bahan komunikasi perusahaan (seperti kartu bisnis, kop surat, dan lain-lain).

Dalam riset selanjutnya, Parasuraman, Zeithaml, dan Berry (1988) (dalam Tjiptono, 2011) menemukan adanya overlapping di antara beberapa dimensi di atas. Oleh demikian, disederhanakan sepuluh dimensi tersebut menjadi lima dimensi pokok. Kompetensi, kesopanan, kredibilitas, dan keamanan disatukan menjadi jaminan (assurance). Sedangkan akses, komunikasi, dan kemampuan memahami pelanggan diintegrasikan menjadi empati (empathy). Dengan demikian, terdapat lima dimensi utama yang disusun sesuai urutan tingkat kepentingan relatifnya adalah sebagai berikut:

1. Tangibles (Bukti fisik)

Tangibles (bukti fisik), berkenaan dengan daya tarik fasilitas fisik, perlengkapan, dan material yang digunakan perusahaan, serta penampilan karyawan.

2. Reliability (Reliabilitas)

Reliability (reliabilitas), berkaitan dengan kemampuan perusahaan untuk memberikan layanan yang akurat sejak pertama kali tanpa membuat kesalahan apapun dan menyampaikan jasanya sesuai dengan waktu yang disepakati.

3. Responsiveness (Daya tanggap)

Responsiveness (daya tanggap), berkenaan dengan kesediaan dan kemampuan para karyawan untuk membantu para pelanggan dan merespon permintaan mereka, serta me-nginformasikan kapan jasa akan diberikan dan kemudian memberikan jasa secara cepat.

4. Assurance (Jaminan)

Assurance (jaminan), yakni perilaku para karyawan mampu menumbuhkan kepercayaan pelanggan terhadap perusahaan dan perusahaan bisa menciptakan rasa aman bagi para pelanggannya. Jaminan juga berarti bahwa para karyawan selalu bersikap sopan dan menguasai pengetahuan dan keterampilan yang dibutuhkan untuk menangani setiap pertanyaan atau masalah pelanggan.

\section{Emphaty (Empati)}


Emphaty (empati), berarti bahwa perusahaan memahami masalah para pelanggannya dan bertindak demi kepen-tingan pelanggan, serta memberikan perhatian personal kepada para pelanggan dan memiliki jam operasi yang nyaman.

\section{Faktor-faktor Penyebab Buruknya Kualitas Pelayanan}

Beberapa faktor-faktor poten-sial yang bisa menyebabkan buruknya kualitas pelayanan yang diberikan oleh penyelenggara jasa kepada konsumen jasa.

1. Produksi dan konsumsi yang terjadi secara simultan

Salah satu karakteristik unik jasa adalah inseparability, artinya jasa diproduksi dan dikonsumsi pada saat bersamaan. Hal ini sering membutuhkan kehadiran dan partisipasi pelanggan dalam proses penyampaian jasa. Konsekuensinya, berbagai macam persoalan sehu-bungan dengan interaksi antara penyedia jasa dan pelanggan jasa bisa saja terjadi. Beberapa kelemahan yang mungkin ada pada karyawan jasa dan mungkin berdampak negatif terhadap persepsi kualitas meliputi (Tjiptono, 2011):

a) Tidak terampil dalam melayani pelanggan,

b) Cara berpakaian karyawan kurang sesuai dengan konteks,

c) Tutur kata karyawan kurang sopan atau bahkan menyebalkan,

d) Bau badan karyawan meng-ganggu kenyamanan pelanggan,

e) Karyawan selalu cemberut atau pasang tampang "angker".

2. Intensitas tenaga kerja yang tinggi

Menurut Tjiptono (2011) keterlibatan karyawan secara intensif dalam penyampaian jasa dapat pula menimbulkan masalah kualitas, yaitu berupa tingginya variabilitas jasa yang dihasilkan. Faktorfaktor yang bisa mempengaruhinya antara lain: upah rendah (umumnya karyawan yang melayani atau berinteraksi langsung dengan pelanggan memiliki tingkat pendidikan dan upah yang paling rendah dalam sebuah perusahaan), pelatihan yang kurang memadai atau bahkan tidak sesuai dengan kebutuhan organisasi, dan tingkat perputaran karyawan terlalu tinggi.

3. Dukungan terhadap pelanggan internal kurang memadai

Pemberdayaan dalam konteks ini tidak diartikan secara sempit sebagai sekedar penghapusan hirarki, arahan, atau akuntabilitas pribadi. Akan tetapi, pemberdayaan lebih dipandang sebagai state of mind (Berry, 1995) (dalam Tjiptono, 2011). Karyawan dan manajer yang diberdayakan akan lebih mampu:

1) Mengendalikan dan menguasai cara melaksanakan pekerjaan dan tugasnya;

2) Memahami konteks di mana pekerjaannya dilaksanakan dan kesesuaian pekerjaannya dalam kerangka pekerjaan yang lebih luas (big picture);

3) Bertanggung jawab atas output kerja pribadi;

4) Mengemban tanggung jawab bersama atas kinerja unit dan organisasi;

5) Menjamin keadilan dalam distribusi balas jasa berdasarkan kinerja individual dan kinerja kolektif.

\section{Gap komunikasi}

Komunikasi merupakan faktor esensial dalam menjalin kontak dan relasi dengan pelanggan. Bila terjadi gap komunikasi, maka bisa timbul penilaian atau persepsi negatif terhadap kualitas jasa. Gap komunikasi bisa berupa (Tjiptono, 2011):

1) Penyedia jasa memberikan janji berlebihan, sehingga tidak mampu memenuhinya.

2) Penyedia jasa tidak bisa selalu menyajikan informasi terbaru kepada para pelanggan, misalnya yang berkaitan dengan perubahan prosedur/aturan.

3) Pesan komunikasi penyedia jasa tidak dipahami pelanggan. 
4) Penyedia jasa tidak memperhatikan atau tidak segera menanggapi keluhan dan saran pelanggan.

5. Memperlakukan pelanggan de-ngan cara yang sama

Menurut Tjiptono (2011) pelanggan merupakan individu unik dengan preferensi, perasaan, dan emosi masingmasing. Dalam hal interaksi dengan penyedia jasa, tidak semua pelanggan bersedia menerima jasa yang seragam (standardized services). Sering terjadi ada pelanggan yang menginginkan atau bahkan menuntut jasa yang sifatnya personal dan berbeda dengan pelanggan lain. Hal ini memunculkan tantangan bagi penyedia jasa dalam hal kemampuan memahami kebutuhan spesifik pelanggan individual dan memahami perasaan pelanggan terhadap penyedia jasa dan layanan yang mereka terima.

\section{Perluasan atau pengembangan jasa} secara berlebihan

Memperkenalkan jasa baru atau menyempurnakan jasa lama dapat meningkatkan peluang pertumbuhan bisnis dan menghindari terjadinya layanan yang buruk. Di sisi lain, bila terlalu banyak jasa baru dan tambahan terhadap jasa yang sudah ada, hasil yang didapatkan belum tentu optimal, bahkan tidak tertutup kemungkinan timbul masalah-masalah seputar standar kualitas jasa. Selain itu, pelanggan juga bisa bingung membedakan variasi penawaran jasa, baik dari segi fitur, keunggulan, maupun tingkat kualitasnya (Tjiptono, 2011).

\section{Visi bisnis jangka pendek}

Visi jangka pendek (misalnya, orientasi pada pencapaian target penjualan dan laba tahunan, penghematan biaya sebesar-besarnya, peningkatan produktivitas tahunan, dan lain-lain) bisa merusak kualitas pelayanan yang sedang dibentuk untuk jangka panjang (Tjiptono, 2011).

\section{Model SERVQUAL}

Model kualitas jasa yang paling populer dan hingga kini banyak dijadikan acuan dalam riset manajemen dan pemasaran jasa adalah model SERVQUAL (singkatan dari service quality) yang dikembangkan oleh Parasuraman, Zeithaml, dan Berry (1985, 1988, 1990, 1991, 1993, 1994) (dalam Tjiptono, 2011). Dalam serangkaian penelitian mereka terhadap enam sektor jasa: reparasi peralatan rumah tangga, kartu kredit, asuransi, sambungan telepon interlokal, perbankan ritel, dan pialang sekuritas. Model yang dikenal pula dengan istilah Gap Analysis Model ini berkaitan erat dengan kepuasan pelanggan yang didasarkan pada perkiraan diskonfirmasi (Oliver, 1997) (dalam Tjiptono, 2011). Perkiraan ini menegaskan bahwa bila kinerja pada suatu atribut (attribute performance) meningkat lebih besar daripada harapan (expectations) atas atribut bersangkutan, maka persepsi terhadap kualitas jasa akan positif dan sebaliknya.

Perjalanan panjang perkem-bangan model SERVQUAL bisa ditelusuri pada delapan tahap utama: kelahiran, instrumentasi, extended gaps model, determinan ekspektasi jasa, revisi instrumen SERVQUAL, dampak SERVQUAL terhadap minat behavioral, sistem informasi kualitas jasa, dan eSERVQUAL.

\section{Dampak Kualitas Pelayanan}

Kualitas pelayanan berdampak pada lima gap utama yang terangkum dalam SERVQUAL meliputi:

1. Gap antara harapan pelanggan dan persepsi manajemen (Knowledge gap). Gap ini berarti bahwa pihak manajemen mempersepsikan ekspektasi pelanggan terhadap kualitas jasa secara tidak akurat. Beberapa kemungkinan penyebabnya antara lain: informasi yang didapatkan dari riset pasar dan analisis permintaan kurang 
akurat; interpretasi yang kurang akurat atas informasi mengenai ekspektasi pelanggan; tidak adanya analisis permintaan; buruknya atau tiadanya aliran informasi ke atas (upward information) dari staf kontak pelanggan ke pihak manajemen; dan terlalu banyak jenjang manajerial yang menghambat atau mengubah informasi yang disampaikan dari karyawan kontak pelanggan ke pihak manajemen.

2. Gap antara persepsi manajemen terhadap harapan konsumen dan spesifikasi kualitas jasa (Standard gap).

Gap ini berarti bahwa spesifikasi kualitas jasa tidak konsisten dengan persepsi manajemen terhadap ekspektasi kualitas. Penyebabnya antara lain: tidak adanya standar kinerja yang jelas; kesalahan perencanaan atau prosedur perencanaan yang tidak memadai; manajemen perencanaan yang buruk; kurangnya penetapan tujuan yang jelas dalam organisasi; kurangnya dukungan dan komitmen manajemen puncak terhadap perencanaan kualitas jasa; kekurangan sumber daya; dan situasi permintaan berlebihan.

3. Gap antara spesifikasi kualitas jasa dan penyampaian jasa (Delivery gap)

Gap ini berarti bahwa spesifikasi kualitas tidak terpenuhi oleh kinerja dalam proses produksi dan penyampaian jasa. Sejumlah penyebabnya antara lain: spesifikasi kualitas terlalu rumit dan atau terlalu kaku; para karyawan tidak menyepakati spesifikasi tersebut dan karenanya tidak memenuhinya; spesifikasi tidak sejalan dengan budaya korporat yang ada; manajemen operasi jasa yang buruk; kurang memadainya aktivitas internal marketing; serta teknologi dan sistem yang ada tidak memfasilitasi kinerja sesuai dengan spesifikasi. Kurang terlatihnya karyawan, beban kerja terlampau berlebihan, dan standar kinerja tidak dapat dipenuhi karyawan (terlalu tinggi realistis) juga bisa menyebabkan terjadinya gap ini. Selain itu, mungkin pula keryawan dihadapkan pada pada standar-standar yang kadangkala saling bertentangan satu sama lain.

4. Gap antara penyampaian jasa dan komunikasi eksternal (Communications gap)

Gap ini berarti bahwa janji-janji yang disampaikan melalui aktivitas komunikasi pemasaran tidak konsisten dengan jasa yang disampaikan kepada para pelanggan. Hal ini bisa disebabkan oleh beberapa faktor, diantaranya: perencanaan komunikasi pemasaran tidak terintegrasi dengan operasi jasa; kurangnya koordinasi antara aktivitas pemasaran eksternal dan operasi jasa; organisasi gagal memenuhi spesifikasi yang ditetapkannya, sementara kampanye komunikasi pemasaran sesuai dengan spesifikasi tersebut; dan kecenderungan untuk melakukan"over-promise", underdeliver". Iklan atau slogan janji perusahaan seringkali mempengaruhi ekspektasi pelanggan. Jika penyedia jasa memberikan janji berlebihan, maka resikonya harapan pelanggan bisa membumbung tinggi dan sulit dipenuhi.

5. Gap antara jasa yang dipersepsikan dan jasa yang diharapkan (Service gap).

Gap ini berarti bahwa jasa yang dipersepsikan tidak konsisten dengan jasa yang diharapkan. Gap ini bisa menimbulkan sejumlah konsekuensi negatif, seperti kualitas buruk (negatively confirmed quality) dan masalah kualitas; komunikasi gethok tular yang negatif; dampak negatif terhadap citra korporat atau citra local; dan kehilangan pelanggan. Gap ini 
terjadi apabila pelanggan mengukur kinerja atau prestasi perusahaan berdasarkan kriteria yang berbeda atau bisa juga mereka keliru mempersepsikan kualitas jasa bersangkutan.

Dalam teori kualitas pelayanan yang disampaikan oleh Parasuraman dkk (1983) terdapat penjelasan yang lebih rinci mengenai lima gap yang menyebabkan terjadinya gab kualitas jasa dan kinerja. Salah satu gap tersebut adalah gap antara spesifikasi kualitas jasa dan penyampaian jasa (Delivery gap).

\section{Kepuasan Kerja dan Kualitas Layanan}

Efek kepuasan kerja mempengaruhi kualitas pelayanan karyawan terhadap pelanggan. Hasilnya kepuasan kerja itu sendiri memberikan efek terhadap kualitas pelayanan yang diberikan. Dengan demikian kepuasan kerja ini memiliki hubungan sebab-akibat dengan kualitas pelayanan.

Hubungan antara kepuasan kerja dan kualitas pelayanan dipengaruhi oleh berbagai aspek disetiap variabel tersebut. Seperti kepuasan kerja memiliki 9 aspek yang mempengaruhi kepuasan kerja menurut Spector (1997), antara lain :

1. Kepuasan kerja tehadap gaji yang diterima dan kesempatan memperoleh kenaikan gaji.

2. Kepuasan kerja terhadap kesempatan promosi untuk kenaikan jabatan.

3. Kepuasan kerja terhadap atasan.

4. Kepuasan kerja terhadap tunjangantunjangan diluar gaji (fringe benefits).

5. Kepuasan kerja terhadap reward yang diterima saat karyawan menunjukan performa yang baik atau prestasi dalam pekerjaan, tidak selalu berupa uang (contingent rewards).

6. Kepuasaan kerja terhadap kondisi perusahaan, termasuk mengenai peraturan serta prosedurnya.
7. Kepuasan kerja terhadap rekan sejawat, termasuk interaksi dan kerjasama dengan sesama rekan kerja.

8. Kepuasaan kerja terhadap tipe pekerjaan yang harus dikerjakan.

Sedangkan menurut Para-suraman (1990) menyatakan bahwa kualitas pelayanan menurut para pelanggan didefinisikan sebagai perbedaan antara persepsi pelanggan dan harapan pelanggan atau keinginan pelanggan terhadap pelayanan yang diterima. Hal ini dapat diukur dengan lima aspek yang mempengaruhi kualitas pelayanan yaitu:

1. Tangibles (bukti fisik) adalah dimensi yang berkenaan dengan daya tarik fasilitas fisik seperti, perlengkapan, dan peralatan yang digunakan (teknologi).

2. Reliability (reliabilitas) adalah dimensi yang berkenaan dengan kemampuan untuk memberikan pelayanan sesuai dengan apa yang dijanjikan. Kinerja setiap karyawan harus sesuai dengan harapan konsumen dan sikap simpatik dalam memberikan pelayanan.

3. Responsiveness (daya tanggap) adalah dimensi yang berkenaan dengan kesediaan dan kemampuan untuk membantu para konsumen dan merespon permintaan mereka, serta menginformasikan kapan jasa akan diberikan dan memberikan jasa secara cepat.

4. Assurance (jaminan) adalah dimensi yang berupa pengetahuan, kemampuan, kesopanan serta sikap yang dapat dipercaya, bebas dari bahaya, resiko atau keragu-raguan dalam melaksanakan tugas serta tanggung jawab tanpa dengan adanya pengawasan yang sangat ketat, tetapi berdasarkan sadar disiplin.

5. Emphaty (empati) adalah dimensi yang berkaitan dengan perhatian dalam memberikan sikap yang tulus.

\section{Simpulan}


Pelayanan yang unggul tidak akan terwujud jika tidak ada kepuasan kerja karyawan. Sehingga berdampak pada kualitas pelayanan yang diberikan oleh karyawan. Dapat disimpulkan bahwa kepuasan kerja berkaitan dengan persepsi terhadap kualitas pelayanan. Apabila persepsi karyawan baik dan positif terhadap kepuasan kerja, maka akan terjadi kualitas pelayanan yang baik, apabila yang terjadi sebaliknya maka akan tercipta kualitas pelayanan yang buruk.

\section{DAFTAR RUJUKAN}

As'ad, Moh. 2012. Seri Ilmu Sumber Daya Manusia: Psikologi Industri edisi 4. Yogyakarta: Liberty.

Bata, Yuristi Winda., Arifin, Alwy., Darmawansyah. 2013. Hubungan Kualitas Pelayanan Kesehatan Dengan Kepuasan Pasien Pengguna Askes Sosial Pada Pelayanan Rawat Inap di Rsud Lakipadada Kabupaten Tana Toraja. Makasar: Unhas.

Davis, K \& Newstroom. 1996. Perilaku dalam Organisasi Edisi 7. Jakarta: Erlangga.

Donnelly, Gibson. 1996. Organisasi, Perilaku, Struktur, dan Proses. Jakarta: Erlangga.

Handoko, Hani. 2012. Manajemen Personalia dan Sumberdaya Manusia. Yogyakarta: BPFE. . 1992. Manajemen, Edisi II, Cetakan keenam. Yogyakarta: BPFE.

Husodo, Norviadi Setio. 2004. Tesis: Pengaruh Kepuasan Kerja Pegawai Terhadap Kualitas
Pelayanan Museum Seni Rupa dan Keramik. Jakarta: Fisip UI.

Indrayanti,. Kadir,. Pasinringi,. 2008. Hubungan Kualitas Pelayanan Internal Terhadap Kepuasan Kerja dan Kemampuan Petugas Memberikan Pelayanan Berkualitas di RSUD Lanto Dg Pasewang. Makasar: Magister Manajemen Fakultas Ekonomi Universitas Hasanuddin.

Munandar, A.S. 2001. Psikologi Industri dan Organisasi. Jakarta: Universitas Indonesia (UI-Press).

Parasuraman,. Zeithaml,. Berry. 1990. Delivering Quality Service. New York: The Free Press.

Riggio, Ronald, E. 2009. Introduction to Industrial or Organizational Psychology Ed 5. New Jersey: Pearson Education.

Robbins, Stephen P. Judge, Timothy A. 2001. Perilaku Organisasi. Jakarta: Salemba Empat.

Siagian, MPA, Prof. Dr. Sondang P. 2012. Manajemen Sumber Daya Manusia. Jakarta: Bumi Aksara.

Spector, Paul E. 2012. Industrial and Organizational Psycholog: Research and Practice Ed 6. Singapore: John Wiley \& Sons Inc.

Tjiptono, Fandy., Chandra, Gregorius. 2011. Service, Quality \& Satisfaction Ed 3. Yogyakarta: Penerbit Andi.

Wijono, Sutarto. 2010. Psikologi Industri dan Organisasi. Jakarta: Kencana.

Yuwono, Ino Dkk. 2005. Psikologi Industridan Organisasi. Surabaya: Fakultas Psikologi Universitas Airlangga. 